\title{
Heparan Sulfate Proteoglycans Are Receptors for Extracellular HIV-1 Tat Internalization
}

\section{細胞膜ヘパラン硫酸プロテオグライカンはHIV-1 Tatの細胞内取り込みの受容体である}

\author{
Key Words: HIV-1 Tat protein, heparin, heparan sulfate proteoglycan, internalization
}

Tat protein of human immunodeficiency virus-1 (HIV-1) released by HIV-infected cells is a powerful transcriptional activator of the integrated viral genome and also acts as an extracellular molecule. Tat protein also exerts pleiotropic biological activities when present in the extracellular compartment. Three classes of cell-surface receptors have been implicated in the biological activity of extracellular Tat: cell adhesion receptors of the integrin family, the vascular endothelial growth factor receptors and the chemokine receptors. Extracellular Tat promotes the production of cytokines and cytokine receptors; modulates the survival, proliferation, and migration of different cell types; exerts angiogenic activity in vitro and in vivo; inhibits antigenspecific lymphocyte proliferation; and induces neurotoxicity in the central nervous system. Thus, extracellular Tat is implicated in the progression of AIDS and in the pathogenesis of AIDSassociated pathologies including Kaposi's sarcoma, AIDS-dementia and increased tumor incidence in an autocrine or paracrine fashion.

The interaction of Tat with heparan sulfate proteoglycan (HSPG) is implicated in the internalization of Tat in the cells. Besides the interaction of Tat protein with cell surface receptors and the consequent activation of intracellular signal transduction pathways, many of the activities of extracellular Tat are mediated by its unique property of being rapidly internalized by a variety of cell types. The uptake, internalization, and nuclear translocation of extracellular Tat can also be exploited as a biotechnological tool for intracellular protein delivery. Production of recombinant proteins containing the transduction domain of Tat protein facilitates the intracellular delivery of these proteins. However, the cellular mechanisms for Tat uptake and internalization have been largely unexplored despite the large body of evidence available about the functions of extracellular Tat and its recent use as a biotechnological vector for protein transduction. The authors of the paper introduced here provided genetic and biochemical evidence that cell membrane HSPGs act as receptors for extracellular Tat internalization [Tyagi M., Rusnati M., Presta M., and Giacca M., (2001) J. Biol. Chem., 276, 32543261].

Tat is a heparin-binding protein that interacts with HSPGs of the cell surface and extracellular matrix. This allows the extracellular storage of Tat that can be mobilized in a biologically active form by free heparin. The Tat uptake by CHO K1 cells was competitively inhibited by heparin, but not by other gly-
ヒト免疫不全ウイルスー1(HIV-1)感染細胞から分泌された HIV-1のTatタンパクは、細胞内では組み込まれたウイルス遺伝 子の強力な転写活性化分子である。一方 Tatタンパクが細胞外に 存在する時、多面的な生物活性を有している。細胞外Tat夕ンパ クの生物活性発現に関与する細胞表面レセプターとして3つの種 類、すなわちインテグリンファミリーの細胞接着レセプター、 血管内皮細胞増殖因子レセプター、そしてケモカインレセプ ターが知られている。細胞外に存在するTatタンパクは、サイト カインやサイトカインレセプターの発現を促進し、様々な種類 の細胞の生存、増殖、遊走を変動させ、血管新生を促進し、抗 原特異性リンパ球増殖を抑制し、中枢神経組織の神経毒性を誘 導する。このように、細胞外に存在するTatタンパクは、AIDSの 進行とAIDSに関連した様々な病態、すなわちカポシ肉腫、AIDS 型痴呆、オートクリンあるいはパラクリン型で生じる腫瘍発生 の増加などに深く関与している。

Tatとへパラン硫酸プロテオグライカン(HSPG)の相互作用 は、Tatの細胞内取込みに関連している。Tatタンパクが細胞表面 レセプターと結合し、細胞内シグナル伝達を促進・活性化させ る機構の他に、細胞外Tatタンパクの活性の多くが、Tatの早い細 胞内取込みに依存している。細胞外Tatの細胞表面への結合、細 胞内への取り込み、核への移動等は、タンパク質の細胞内伝搬 のための生物工学的手法としても利用されている。Tatタンパク の形質導入領域を含んだ組み換えタンパク質は、効率的に細胞 内に伝搬される。しかしながら、細胞外Tatの機能についての研 究の進展そしてタンパク質伝搬のための生物工学的応用などに も関わらず、Tatの細胞内取り込みについての細胞生物学的メカ ニズムは、媣く研究されていない。ここで紹介する論文の著者 らは、細胞表面のHSPGは細胞外Tatの細胞内取込みのためのレ セプターとして作用する遺伝学的そして生化学的証明を与えた [Tyagi M., Rusnati M., Presta M., and Giacca M., (2001) J. Biol. Chem., 276, 3254-3261]。

Tatは細胞表面や細胞外マトリックスのHSPGと相互作用す るへパリン結合性タンパク質である。この相互作用により、Tat を細胞外に蓄積させることができる。逆にこの細胞外に蓄積し たTatは、へパリンにより活性型のまま遊離させることができ る。CHO K1細胞によるTatの取り込みは、コンドロイチン硫酸 
cosaminoglycans (GAGs) such as chondroitin sulfate A, B and C. The cell treatment with heparitinase (heparinase III or I), enzymes active on HS or heparin, impaired Tat internalization in a dose-dependent manner. In contrast, the cell treatments with condroitinase $\mathrm{AC}$ and $\mathrm{ABC}$ were completely ineffective in inhibiting Tat internalization.

A series of mutant cell lines originated from CHO K1 cells and defective in GAG biosynthesis were analyzed in order to provide a genetic proof that cell surface HSPG acts as major receptors for Tat internalization. Cells defective in the biosynthesis of fully sulfated HS are selectively impaired in the internalization of recombinant Tat fused to the green fluorescent protein, as evaluated by both flow cytometry and functional assays. In contrast to extracellular Tat uptake, both wild type cells and cells defective in HSPG biosynthesis which were transfected with a Tat-expressing plasmid (pCDNA3-Tat) were equally proficient in the extracellular release of Tat, indicating that HSPGs are not required for extracellular release of Tat by the expressing cells.

Binding affinity of Tat for heparin/HS is proportional to the size of the oligosaccharides, with at least six saccharide residues required for this interaction to occur. Biochemical data also indicate that selective 2-O-, 6-O-, or N- desulfation / N-acetylation dramatically reduces the capacity of heparin to bind Tat. Finally, the requirement of structure recognition for Tat-Heparin/HS interaction to occur is further supported by the observation that several highly negatively charged molecules such as chondroitin sulfate, dextran sulfate, and sulfated $\beta$-cyclodextrin are poor Tat antagonists. Thus, the interaction between Tat and heparin/HS is specific and is determined by size, saccharide composition, and extent and distribution of sulfation of the GAG backbone.

Extracellular Tat has been proposed as a target for pharmacological and immunological approaches in the therapy of AIDS and AIDS-associated pathologies. Besides their Tat-antagonist activity, heparin and polysulfated compounds are known to be able to prevent HIV infection. Their study introduced in this topic may provide significant information to design tailored Tat-antagonist compounds with a favorable therapeutic window.

\section{Reported by Masayuki Ishihara}

National Defense Medical College, Research Institute, 3-2 Namiki, Tokorozawa, Saitama, 359-8513 Japan

FAX: 81-42-991-1611
$\mathrm{A} 、 \mathrm{~B} 、 \mathrm{C}$ な゙のようなグリコサミノグライカン $(\mathrm{GAG})$ でなく、 ヘパリンにより競合的に抑制された。ヘパリン／HSに対する分 解活性をもつへパリチナーゼ(ヘパリナーゼIIIあるいはI)で細胞 を処理すると、濃度依存的にTatの細胞内取込みが抑制された。 対照的にコンドロイチナーゼACあるいはABCで細胞を処理して も Tatの細胞内取込みの抑制は全く観察されなかった。

細胞表面HSPGが Tatの細胞内取込みのための主要なレセプ ターであることが、CHO K1細胞由来でGAG生合成を欠損して いる一連の突然変異細胞株を用いて遺伝学的に証明されてい る。すなわち、十分に硫酸化したHSを合成しない突然変異細胞 株には緑蛍光タンパクを融合した組み換えTatが取り込まれない ことが、フローサイトメトリーや機能アッセイにより明らかに なった。細胞外Tatの取り込みとは対照的に、Tat発現用プラスミ ド(pCDNA3-Tat)を導入した正常型そしてHSPGの生合成を欠損 した変異型の両方の細胞が、Tatを等しく効率的に細胞外に分泌 した。このことは、発現細胞によるTatの細胞外分泌にはHSPG が必要ではないことを示唆している。

ヘパリン /HSに対するTatの結合親和性は、糖鎖サイズに比 例し、この相互作用のために最低限6糖鎖長が必要である。また 生化学的検討で、選択的に2位、6位の脱硫酸化、あるいは N-脱 硫酸化 $/ \mathrm{N}$-アセチル化はへパリンのTatへの結合性を顕著に減衰 させることが示された。さらにコンドロイチン硫酸、デキスト ラン硫酸、硫酸化 $\beta$-サイクロデキストリンのような高く負に電 荷している分子でも Tatの良いアンタゴニストにならないことか ら、Tatとへパリン/HSの相互作用が起こるためには特異的構造 認識が要求されることは明らかである。このように、Tatとへパ リン $/ \mathrm{HS}$ 相互作用は特異的で、GAG骨格のサイズ、糖組成、 硫酸の量と位置分布により決定されると言う事ができる。

細胞外Tatタンパクは、AIDSやAIDS関連病態の治療に関す る、薬理学的そして免疫学的研究の夕ーゲットとして認識され ている。へパリンや関連した多硫酸化物質は、Tat-アンタゴニ ス卜活性に加えて、HIV感染を防ぐことが知られている。この トピックスで紹介した研究は、好ましい治療効果を有するTat アンタゴニスト物質をデザィンするための重要な情報を与える ものと思われる。

防衛医科大防衛医学研究センター

石原雅之 